\title{
Angiotensin receptor blockers and microalbuminuria in hypertensive patients with early (microalbuminuric) stage diabetic nephropathy
}

\author{
TADASHI ARAI ${ }^{1}$ and HIROSHIGE OHASHI ${ }^{2}$ \\ ${ }^{1}$ Department of Internal Medicine, Arai Clinic, 2119-1 Takatomi, Yamagata-city, Gifu 501-2105; \\ ${ }^{2}$ Department of Internal Medicine, Division of Kidney Disease, Gifu Prefectural General \\ Medical Center, 4-6-1 Noishiki, Gifu-city, Gifu 500-8717, Japan
}

Received December 18, 2007; Accepted February 19, 2008

\begin{abstract}
Although protection of the kidneys by reninangiotensin system (RAS) inhibitors is well known, differences in renal protection and the characteristics of RAS inhibitors have not been fully investigated. We randomly allocated 80 patients with hypertension complicated by type 2 diabetes and accompanied by microalbuminuria to 4 groups for treatment with the angiotensin receptor blockers (ARBs) telmisartan, losartan, candesartan and valsartan. Strict antihypertensive therapy was performed for 12 months (target blood pressure: lower than $130 / 80 \mathrm{mmHg}$ ), and renal function was compared. At study completion, all groups achieved the hypotensive target and no difference was noted in blood pressure levels. However, influences on renal function differed. In the telmisartan group in particular, the serum creatinine level was unchanged while the urinary albumin level and protein excretion were significantly decreased, displaying a strong renoprotective effect. These findings suggest that, although renal protection is a class effect of ARBs, the effect of telmisartan is particularly strong.
\end{abstract}

\section{Introduction}

Microalbuminuria is not only a sign of the progression of renal impairment, but is also an independent risk factor of cardiovascular events (1). Microalbuminuria was noted in approximately half of type 2 diabetic patients, even though urinary protein was not detected (2). Moreover, its frequency rose as the severity of hypertension increased (3), suggesting that the detection frequency of microalbuminuria in patients with concomitant type 2 diabetes and hypertension is very high. Since the renal and cardiovascular risks of these patients

Correspondence to: Dr Tadashi Arai, Department of Internal Medicine, Arai Clinic, 2119-1 Takatomi, Yamagata-city, Gifu 501-2105, Japan

E-mail: gihoku-arai@nifty.com

Key words: angiotensin receptor blocker, telmisartan, renal protection, microalbuminuria are high, aggressive therapy is necessary from an early stage. Strict glycemic and blood pressure control by the inhibition of the renin-angiotensin system (RAS) in the microalbuminuric stage has been suggested in order to inhibit the transition to manifest nephropathy and to normalize microalbuminuria (4).

Although RAS inhibitors have been demonstrated to inhibit the progression of diabetic nephropathy in large-sale clinical studies $(5,6)$, no study has directly compared the renoprotective effects of RAS inhibitors, and differences in the actions of the various drugs have not been fully investigated. In this study, we strictly controlled blood pressure in patients with early diabetic nephropathy (stage 2) by monotherapy with the angiotensin receptor blockers (ARBs) telmisartan, valsartan, candesartan or losartan, and prospectively investigated the effects of these anti-hypertensive drugs on renal protection.

\section{Patients and methods}

Eighty subjects with concomitant type 2 diabetes and hypertension were diagnosed with early nephropathy (stage 2 ) at the outpatient clinic of two institutions (Arai Clinic and Gifu Prefectural General Medical Center). Patient ages ranged from 60 to $<85$ years (Table I). A causal blood pressure measured at the outpatient clinic of $140 / 90 \mathrm{mmHg}$ or higher was diagnosed as hypertension. As for diabetes, patients undergoing diet and exercise therapy were selected. The criterion for early nephropathy was 30-299 mg/day urinary albumin in 24-h urine.

Patients meeting the above criteria were randomly allocated to 4 groups of 20 for treatment with telmisartan, valsartan, candesartan or losartan, and were prospectively followed for 12 months. The target blood pressure was $<130 / 80 \mathrm{mmHg}$, and the dose of the anti-hypertensive drug was increased when this target was not achieved. The study objective and method were fully explained to the subjects, and written informed consent was obtained.

Causal blood pressure at the outpatient clinic, the serum creatinine level, creatinine clearance and urinary albumin level were measured before test drug administration (baseline) and after 2, 4, 6 and 12 months of administration. HbAlc was measured before and after administration for 12 months.

Changes in the evaluation parameters after test drug administration were analyzed by analysis of variance. Changes 
Table I. Patient demographics and characteristics at baseline.

\begin{tabular}{lcccc}
\hline Variable & $\begin{array}{c}\text { Telmisartan } \\
(\mathrm{n}=20)\end{array}$ & $\begin{array}{c}\text { Valsartan } \\
(\mathrm{n}=20)\end{array}$ & $\begin{array}{c}\text { Candesartan } \\
(\mathrm{n}=20)\end{array}$ & $\begin{array}{c}\text { Losartan } \\
(\mathrm{n}=20)\end{array}$ \\
\hline Age (years) & $74.3 \pm 4.4$ & $73.6 \pm 5.0$ & $73.3 \pm 5.5$ & $72.6 \pm 4.7$ \\
No. male (\%) & $10(50)$ & $10(50)$ & $10(50)$ & $10(50)$ \\
No. statin (\%) & $2(10)$ & $1(5)$ & $3(15)$ & $2(10)$ \\
\hline
\end{tabular}

following 12 months of administration were analyzed using the paired t-test, and changes in the parameters were compared among the test drugs using the unpaired t-test. $\mathrm{p}<0.05$ was set as the level of clinical significance. The values were presented as the means $\pm \mathrm{SD}$.

\section{Results}

Eighty patients meeting the inclusion criteria were randomly allocated to the test groups, each consisting of 20 patients. No significant differences were noted in the systolic/diastolic blood pressure, creatinine clearance or serum creatinine levels of the groups. At 12 months, the mean doses of, telmisartan, valsartan, candesartan and losartan were $48.0 \pm 16.4,116.0 \pm 40.8,10.2 \pm 2.0$ and $71.3 \pm 21.9 \mathrm{mg} / \mathrm{day}$, respectively.

Blood pressure achieved the target value after test drug administration for 12 months, with no differences among the groups. Slight changes in the serum creatinine level were noted in all groups, the smallest of these being in the telmisartan group. Creatinine clearance was decreased in all groups.

The urinary albumin level was decreased in all groups, but the decrease from baseline was significant only in the telmisartan group (Table II). At 12 months, a significant reduction of $28.7 \%$ was observed in the telmisartan group as compared to the baseline (Fig. 1).

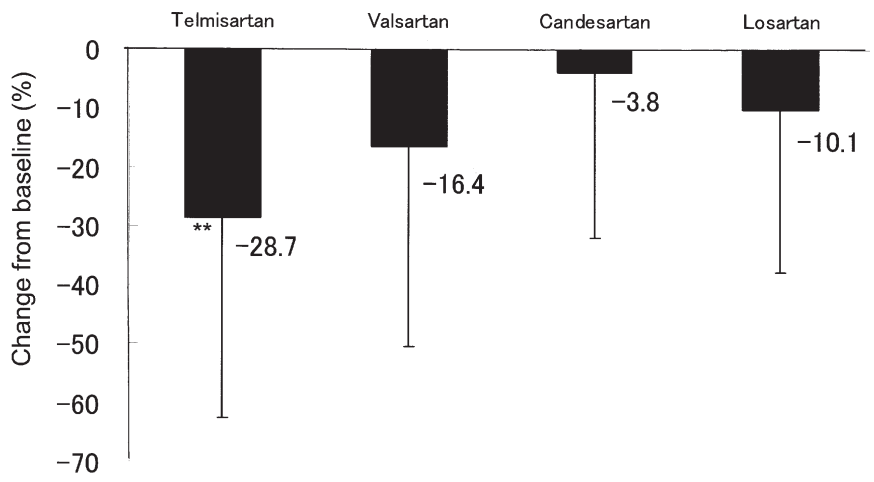

Figure 1. Comparison of the changes in urinary albumin levels from baseline after 12 months of treatment in the ARB groups $(n=20)$. Statistical analysis was performed by the paired t-test. Values are presented as the means \pm SD. ${ }^{* *} \mathrm{p}<0.01$ (vs. baseline by ANOVA).

In the telmisartan group, $\mathrm{HbA} 1 \mathrm{c}$ levels were significantly decreased to $6.1 \%$ from the baseline $6.3 \%$ after 12 months, but no significant change was noted in any other ARB group.

No adverse effects necessitated the discontinuation of test drug administration, and all test drugs were well tolerated.

\section{Discussion}

Patients with concomitant hypertension and type 2 diabetes accompanied by microalbuminuria received strict antihypertensive treatment with ARBs for 12 months. All groups achieved the target blood pressure, but significant differences were noted in the change in serum creatinine levels, creatinine clearance and urinary albumin levels; the serum creatinine level was not elevated. In all groups, the serum creatinine level and urinary albumin level were decreased, indicating renal protection. This was the case particularly in the telmisartan group, in which the serum creatinine level was unchanged and the urinary albumin level was significantly decreased, exhibiting potent protection of renal function.

Table II. Comparison of the change in various parameters during the study.

\begin{tabular}{|c|c|c|c|c|c|c|c|c|c|c|c|c|}
\hline \multirow[b]{2}{*}{ Variable } & \multicolumn{3}{|c|}{ Telmisartan $(\mathrm{n}=20)$} & \multicolumn{3}{|c|}{ Valsartan $(n=20)$} & \multicolumn{3}{|c|}{ Candesartan $(n=20)$} & \multicolumn{3}{|c|}{ Losartan $(n=20)$} \\
\hline & Baseline & 12 months & p-value & Baseline & 12 months & p-value & Baseline & 12 months & $\mathrm{p}$-value & Baseline & 12 months & p-value \\
\hline $\begin{array}{l}\text { Systolic blood } \\
\text { pressure }(\mathrm{mmHg})\end{array}$ & $171.3 \pm 8.0$ & $128.3 \pm 2.2$ & $<0.001$ & $176.4 \pm 9.4$ & $128.2 \pm 1.8$ & $<0.001$ & $176.7 \pm 7.9$ & $128.2 \pm 1.8$ & $<0.001$ & $176.9 \pm 7.2$ & $128.5 \pm 2.0$ & $<0.001$ \\
\hline $\begin{array}{l}\text { Diastolic blood } \\
\text { pressure }(\mathrm{mmHg})\end{array}$ & $86.9 \pm 4.3$ & $75.0 \pm 5.6$ & $<0.001$ & $85.0 \pm 5.6$ & $72.6 \pm 4.3$ & $<0.001$ & $87.5 \pm 5.5$ & $73.6 \pm 4.4$ & $<0.001$ & $86.3 \pm 5.2$ & $70.1 \pm 5.9$ & $<0.001$ \\
\hline $\begin{array}{l}\text { Creatinine } \\
\text { clearance }(\mathrm{ml} / \mathrm{min})\end{array}$ & $77.8 \pm 6.4$ & $69.9 \pm 11.4$ & 0.003 & $68.2 \pm 10.8$ & $62.5 \pm 9.0$ & 0.004 & $72.5 \pm 11.6$ & $65.1 \pm 12.7$ & $<0.001$ & $71.0 \pm 9.8$ & $61.1 \pm 10.4$ & $<0.001$ \\
\hline $\begin{array}{l}\text { Serum creatinine } \\
(\mathrm{mg} / \mathrm{ml})\end{array}$ & $21 \pm 0.03$ & $1.21 \pm 0.03$ & 0.641 & $1.20 \pm 0.04$ & $1.27 \pm 0.03$ & $<0.001$ & $1.19 \pm 0.02$ & $1.27 \pm 0.03$ & $<0.001$ & $1.20 \pm 0.03$ & $1.26 \pm 0.02$ & $<0.001$ \\
\hline $\begin{array}{l}\text { Urinary albumin } \\
\text { excretion (mg/day) }\end{array}$ & $81.4 \pm 18.3$ & $57.2 \pm 27.1$ & 0.001 & $80.0 \pm 17.2$ & $66.0 \pm 27.7$ & 0.043 & $82.3 \pm 17.1$ & $81.2 \pm 33.4$ & 0.839 & $80.8 \pm 19.2$ & $74.2 \pm 31.5$ & 0.204 \\
\hline HbA1c (\%) & $6.3 \pm 0.2$ & $6.1 \pm 0.2$ & 0.011 & $6.2 \pm 0.2$ & $6.2 \pm 0.2$ & 0.204 & $6.3 \pm 0.1$ & $6.2 \pm 0.2$ & 0.161 & $6.3 \pm 0.2$ & $6.2 \pm 0.2$ & 0.800 \\
\hline
\end{tabular}


The improvement of diabetic nephropathy by ARBs has been demonstrated in large-scale clinical studies $(5,6)$. In one such study, Telmisartan was shown to exhibit a renoprotective effect equivalent to that of the ACE inhibitor enalapril (7). Currently, the INNOVATION study on renal protection by telmisartan is underway in Japan (8). Excellent results were also presented at the Meeting of the International Society of Hypertension (2006).

Based on the overall findings, although renal protection by ARBs is a class effect, the strength of the effect varies among drugs. Compared to other RAS inhibitors, telmisartan exhibits a marked renoprotective effect. It has a strong binding affinity for AT1 receptors and a long blood half-life, which enables the potent and stable reduction of blood pressure for $24 \mathrm{~h}$ (9). In addition it has characteristics, such as high tissue transfer, not possessed by other ARBs. This may contribute to its reduction of urinary albumin.

HbA1c, a parameter of glucose metabolism, was significantly decreased in the telmisartan group. Telmisartan was reported to activate PPAR $\gamma$ in addition to its AT1 receptor antagonism, indicating that it improves insulin resistance more strongly than other ARBs (10). This improvement of glucose metabolism may be due to its activation of PPAR $\gamma$.

In summary, blood pressure was strictly controlled by treatment with 4 ARBs in patients with concomitant hypertension and type 2 diabetes accompanied by microalbuminuria. The urinary albumin level was reduced in all groups, with the reduction being the most marked in the telmisartan group. These findings suggest that telmisartan has a particularly strong renoprotective action.

\section{Acknowledgements}

We are grateful to Dr Matsuoka (Professor of Hypertension and Cardiorenal Medicine, Dokkyo Medical University) and Dr H. Fujiwara (Emeritus Professor of Internal Medicine, Gifu University) for their helpful advice and discussion.

\section{References}

1. Hillege HL, Fidler V, Diercks GF, van Gilst WH, De Zeeuw D, van Veldhuisen DJ, Gans RO, Janssen WM, Grobbee D and De Jong PE for the Prevention of Renal and Vascular End Stage Disease (PREVEND) Study Group: Urinary albumin excretion predicts cardiovascular and noncardiovascular mortality in general population. Circulation 106: 1777-1782, 2002.

2. Parving HH, Lewis JB, Ravid M, Remuzzi G and Hunsicker LG for the DEMAND investigators: Prevalence and risk factors for microalbuminuria in a referred cohort of type II diabetic patients: a global perspective. Kidney Int 69: 2057-2063, 2006.

3. Agrawal B, Berger A, Wolf K and Luft FC: Microalbuminuria screening by reagent strip predicts cardiovascular risk in hypertension. J Hypertens 14: 223-228, 1996.

4. Gaede P, Tarnow L, Vedel P, Parving HH and Pedersen O: Remission to normoalbuminuria during multifactorial treatment preserves kidney function in patients with type 2 diabetes and microalbuminuria. Nephrol Dial Transplant 19: 2784-2788, 2004.

5. Brenner BM, Cooper ME, De Zeeuw D, Keane WF, Mitch WE, Parving HH, Remuzzi G, Snapinn SM, Zhang Z and Shahinfar S; RENAAL Study Investigators: Effects of losartan on renal and cardiovascular outcomes in patients with type 2 diabetes and nephropathy. N Engl J Med 345: 861-869, 2001.

6. Lewis EJ, Hunsicker LG, Clarke WR, Berl T, Pohl MA, Lewis JB, Ritz E, Atkins RC, Rohde R and Raz I; Collaborative Study Group: Renoprotective effect of the angiotensin-receptor antagonist irbesartan in patients with nephropathy due to type 2 diabetes. N Engl J Med 345: 851-860, 2001.

7. Barnett AH, Bain SC, Bouter P, Karlberg B, Madsbad S, Jervell J and Mustonen J; Diabetics Exposed to Telmisartan and Enalapril Study Group: Angiotensin-receptor blockade versus convertingenzyme inhibition in type 2 diabetes and nephropathy. N Engl J Med 351: 1952-1961, 2004.

8. Makino H, Haneda M, Babazono T, Moriya T, Ito S, Iwamoto Y, Kawamori R, Takeuchi M and Katayama S: The telmisartan renoprotective study from incipient nephropathy to overt nephropathy - rationale, study design, treatment plan and baseline characteristics of the incipient to overt: angiotensin II receptor blocker, telmisartan, Investigation on Type 2 Diabetic Nephropathy (INNOVATION) Study. J Int Med Res 33: 677-686, 2005.

9. Wienen W, Hauel N, Van Meel JC, Narr B, Ries U and Entzeroth M: Pharmacological characterization of the novel nonpeptide angiotensin II receptor antagonist, BIBR 277. Br J Pharmacol 110: 245-252, 1993.

10. Benson SC, Pershadsingh HA, Ho CI, Chittiboyina A, Desai P, Pravenec M, Qi N, Wang J, Avery MA and Kurtz TW: Identification of telmisartan as a unique angiotensin II receptor antagonist with selective PPARgamma-modulating activity. Hypertension 43: 993-1002, 2004. 